Article

\title{
Metal Substitution Effect on a Three-Dimensional Cyanido-Bridged Fe Spin-Crossover Network
}

\author{
Kenta Imoto ${ }^{1}$, Shinjiro Takano ${ }^{1}$ and Shin-ichi Ohkoshi ${ }^{1,2, *}$ \\ 1 Department of Chemistry, School of Science, The University of Tokyo, 7-3-1 Hongo, Bunkyo-ku, \\ Tokyo 113-0033, Japan; imoto@chem.s.u-tokyo.ac.jp (K.I.); stakano@chem.s.u-tokyo.ac.jp (S.T.) \\ 2 Cryogenic Research Center, The University of Tokyo, 2-11-16 Yayoi, Bunkyo-ku, Tokyo 113-0032, Japan \\ * Correspondence: ohkoshi@chem.s.u-tokyo.ac.jp; Tel.: +81-3-5841-4331
}

Received: 4 September 2017; Accepted: 21 September 2017; Published: 24 September 2017

\begin{abstract}
We report the $\mathrm{Co}^{\mathrm{II}}$-substitution effect on a cyanido-bridged three-dimensional $\mathrm{Fe}^{\mathrm{II}}$ spin-crossover network, $\mathrm{Fe}_{2}\left[\mathrm{Nb}(\mathrm{CN})_{8}\right]$ (4-pyridinealdoxime) $)_{8} \cdot 2 \mathrm{H}_{2} \mathrm{O}$. A series of iron-cobalt octacyanidoniobate, $\left(\mathrm{Fe}_{x} \mathrm{Co}_{1-x}\right)_{2}\left[\mathrm{Nb}(\mathrm{CN})_{8}\right](4 \text {-pyridinealdoxime })_{8} \cdot z \mathrm{H}_{2} \mathrm{O}$, was prepared. In this series, the behavior of $\mathrm{Fe}^{\mathrm{II}}$ spin-crossover changes with the $\mathrm{Co}{ }^{\mathrm{II}}$ concentration. As the $\mathrm{Co}^{\mathrm{II}}$ concentration increases, the transition of the spin-crossover becomes gradual and the transition temperature of the spin-crossover shifts towards a lower temperature. Additionally, this series shows magnetic phase transition at a low temperature. In particular, $\left(\mathrm{Fe}_{0.21} \mathrm{Co}_{0.79}\right)_{2}\left[\mathrm{Nb}(\mathrm{CN})_{8}\right](4 \text {-pyridinealdoxime })_{8} \cdot z \mathrm{H}_{2} \mathrm{O}$ exhibits a Curie temperature of $12 \mathrm{~K}$ and a large coercive field of $3100 \mathrm{Oe}$.
\end{abstract}

Keywords: spin-crossover; magnetic phase transition; cyanido-bridged metal assembly; metal substitution

\section{Introduction}

The spin-crossover phenomenon between low-spin (LS) and high-spin (HS) states has been extensively studied in many fields [1-13]. This phenomenon can be modulated by various physical and chemical stimulations (e.g., light, pressure, temperature, vapor molecule, and metal substitution), and it has potential for sensor and memory applications [14,15]. To control the spin-crossover behavior, the metal substitution effect on the spin-crossover behavior for some $\mathrm{Fe}^{\mathrm{II}}$ spin-crossover materials has been investigated [16-25].

In the field of molecule-based magnets [26-30], cyanido-bridged metal assemblies have drawn attention because they exhibit various magnetic functionalities such as a high Curie temperature $\left(T_{c}\right)$ [31-34], a charge transfer transition [35-42], and an externally stimulated phase transition phenomena [43-47]. In the recent years, we have synthesized several kinds of magnetic cyanido-bridged bimetal assemblies possessing Fe spin-crossover sites. For example, $\mathrm{CsFe}\left[\mathrm{Cr}(\mathrm{CN})_{6}\right] \cdot 1.3 \mathrm{H}_{2} \mathrm{O}$ exhibits a spin-crossover phenomenon at $211 \mathrm{~K}$ in the cooling process $\left(T_{1 / 2} \downarrow\right)$ and $238 \mathrm{~K}$ in the heating process $\left(T_{1 / 2} \uparrow\right)$, and a ferromagnetic phase transition at $9 \mathrm{~K}$ [48]. $\mathrm{Fe}_{2}\left[\mathrm{Nb}(\mathrm{CN})_{8}\right](3 \text {-pyridylmethanol })_{8} \cdot 4.6 \mathrm{H}_{2} \mathrm{O}$ shows a gradual spin-crossover phenomenon at $250 \mathrm{~K}$ and a ferrimagnetic phase transition at $12 \mathrm{~K}$ [49]. However, the photoresponsivities were not reported for these compounds.

In 2011, we synthesized a cyanido-bridged metal assembly, $\mathrm{Fe}_{2}\left[\mathrm{Nb}(\mathrm{CN})_{8}\right]$ (4-pyridinealdoxime) $)_{8} \cdot 2 \mathrm{H}_{2} \mathrm{O}$, which shows a spin-crossover phenomenon at $130 \mathrm{~K}$ [50]. When this material is irradiated with 473-nm light, a spontaneous magnetization is observed. This photoinduced ferrimagnetic phase exhibits a $T_{\mathrm{C}}$ value of $20 \mathrm{~K}$ and a coercive field $\left(H_{\mathrm{c}}\right)$ value of $240 \mathrm{Oe}$. This is the first demonstration of light-induced spin crossover ferrimagnetism. In 2014, we prepared $\mathrm{Fe}_{2}\left[\mathrm{Nb}(\mathrm{CN})_{8}\right]$ (4-bromopyridine $)_{8} \cdot 2 \mathrm{H}_{2} \mathrm{O}$, which is the first chiral photomagnet, and observed $90^{\circ}$ optical switching of the polarization plane of second harmonic light [51]. 
From the viewpoint of controlling the magnetic performance of a photomagnetic material, metal replacement is effective. In particular, $\mathrm{Co}_{2}\left[\mathrm{Nb}(\mathrm{CN})_{8}\right](4 \text {-pyridinealdoxime })_{8} \cdot 2 \mathrm{H}_{2} \mathrm{O}$, which is a metal-substituted compound of $\mathrm{Fe}_{2}\left[\mathrm{Nb}(\mathrm{CN})_{8}\right]$ (4-pyridinealdoxime) $)_{8} \cdot 2 \mathrm{H}_{2} \mathrm{O}$ described above as the first photoinduced spin-crossover magnet, shows a large coercive field of 15,000 Oe [52]. In this work, we synthesize cyanido-bridged metal assemblies containing both Fe and Co ions, $\left(\mathrm{Fe}_{1-x} \mathrm{Co}_{x}\right)_{2}\left[\mathrm{Nb}(\mathrm{CN})_{8}\right](4-\text { pyridinealdoxime })_{8} \cdot z \mathrm{H}_{2} \mathrm{O}$, and discuss the crystal structures, spectroscopic properties, and magnetic properties.

\section{Results and Discussions}

\subsection{Syntheses}

The preparation of $\left(\mathrm{Fe}_{1-x} \mathrm{Co}_{x}\right)_{2}\left[\mathrm{Nb}(\mathrm{CN})_{8}\right](4-\text { pyridinealdoxime })_{8} \cdot z \mathrm{H}_{2} \mathrm{O}$ was performed by reacting a mixed aqueous solution of $\mathrm{FeCl}_{2} \cdot 4 \mathrm{H}_{2} \mathrm{O}, \mathrm{CoCl}_{2} \cdot 6 \mathrm{H}_{2} \mathrm{O}, \mathrm{L}-(+)$-ascorbic acid, and 4-pyridinealdoxime, with an aqueous solution of $\mathrm{K}_{4}\left[\mathrm{Nb}(\mathrm{CN})_{8}\right] \cdot 2 \mathrm{H}_{2} \mathrm{O}$ with $\mathrm{Fe} / \mathrm{Co}$ ratios $[\mathrm{Fe}] /([\mathrm{Fe}]+[\mathrm{Co}])$ of $0,0.1$, $0.25,0.5,0.75$, and 1 , yielding a microcrystalline powder. Stirring was continued for $1 \mathrm{~h}$. Then the solution was filtered and washed twice by water. Elemental analyses indicate that the chemical formulae of the obtained compounds are $\mathrm{Fe}_{2}\left[\mathrm{Nb}(\mathrm{CN})_{8}\right](4 \text {-pyridinealdoxime })_{8} \cdot 3 \mathrm{H}_{2} \mathrm{O}$ $\left(x=0\right.$, compound 1), $\left(\mathrm{Fe}_{0.92} \mathrm{Co}_{0.08}\right)_{2}\left[\mathrm{Nb}(\mathrm{CN})_{8}\right](4 \text {-pyridinealdoxime })_{8} \cdot 3 \mathrm{H}_{2} \mathrm{O}(x=0.08$, compound 2$)$, $\left(\mathrm{Fe}_{0.71} \mathrm{Co}_{0.29}\right)_{2}\left[\mathrm{Nb}(\mathrm{CN})_{8}\right](4-\text { pyridinealdoxime })_{8} \cdot 3 \mathrm{H}_{2} \mathrm{O}(x=0.29$, compound 3$),\left(\mathrm{Fe}_{0.50} \mathrm{Co}_{0.50}\right)_{2}\left[\mathrm{Nb}(\mathrm{CN})_{8}\right]$ (4-pyridinealdoxime $)_{8} \cdot 3 \mathrm{H}_{2} \mathrm{O}\left(x=0.50\right.$, compound 4), $\left(\mathrm{Fe}_{0.21} \mathrm{Co}_{0.79}\right)_{2}\left[\mathrm{Nb}(\mathrm{CN})_{8}\right](4 \text {-pyridinealdoxime })_{8} \cdot 3 \mathrm{H}_{2} \mathrm{O}$ ( $x=0.79$, compound 5), and $\mathrm{Co}_{2}\left[\mathrm{Nb}(\mathrm{CN})_{8}\right](4-\text { pyridinealdoxime })_{8} \cdot 3 \mathrm{H}_{2} \mathrm{O}(x=1$, compound 6). (See Section 3$)$ The compounds of $\mathbf{1}$ and $\mathbf{6}$ in this work correspond well to the formulae in our previous reports [50,52].

\subsection{Crystal Structures and Spectroscopic Properties}

Table 1 and Figure 1 show the results of the Rietveld analyses of the powder X-ray diffraction (XRD) patterns for 1-6. Structural analyses show that the crystal structures of $\mathbf{1}$ and $\mathbf{6}$ are isostructural to those reported in our previous papers [50,52]. Rietveld analyses of the XRD patterns of $\mathbf{2}-\mathbf{5}$ were performed using the crystal structure of $\mathbf{1}$ as the initial structure with the occupancies of Fe and Co based on the chemical formula. The lattice constant versus $x$ value (Co content) plot shows that the lattice constant of the $a$-axis decreases from $20.2893 \AA(x=0)$ to $20.2105 \AA(x=1)(0.4 \%$ decrease), while that of the $c$-axis slightly decreases from $15.0224 \AA(x=0)$ to $15.0066 \AA(x=1)(0.1 \%$ decrease), and the unit cell volume decreases from $6184.1 \AA^{3}(x=0)$ to $6129.7 \AA^{3}(x=1)(0.9 \%$ decrease $)$ with increasing $x$ value (Table 1, Figure 2). It is noteworthy that the XRD peaks become broader with an increasing $x$ value. The SEM images indicate that this broadening is caused by the reduction of the crystallite size (Figure S1).

Table 1. Crystal system, space group, and lattice constants of 1-6.

\begin{tabular}{ccccccc}
\hline & $\mathbf{1}$ & $\mathbf{2}$ & $\mathbf{3}$ & $\mathbf{4}$ & $\mathbf{5}$ & $\mathbf{6}$ \\
\hline Crystal system & Tetragonal & Tetragonal & Tetragonal & Tetragonal & Tetragonal & Tetragonal \\
\hline Space group & $I 4_{1} / a$ & $I 4_{1} / a$ & $I 4_{1} / a$ & $I 4_{1} / a$ & $I 4_{1} / a$ & $I 4_{1} / a$ \\
\hline$a(b) / \AA$ & $20.2893(5)$ & $20.2683(5)$ & $20.2572(6)$ & $20.2453(8)$ & $20.2203(12)$ & $20.2105(1)$ \\
$c / \AA$ & $15.0224(5)$ & $15.0156(5)$ & $15.0154(6)$ & $15.0151(8)$ & $15.0047(13)$ & $15.0066(13)$ \\
$V / \AA^{3}$ & $6184.1(3)$ & $6168.5(3)$ & $6161.6(3)$ & $6154.2(5)$ & $6134.8(8)$ & $6129.7(7)$ \\
\hline
\end{tabular}


1

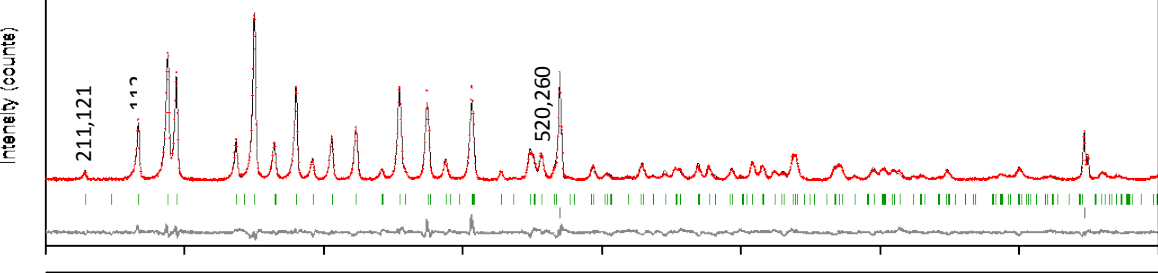

2

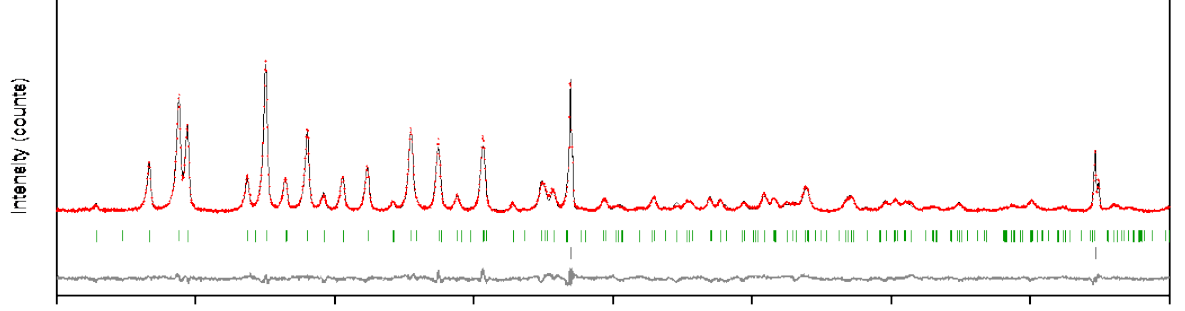

3

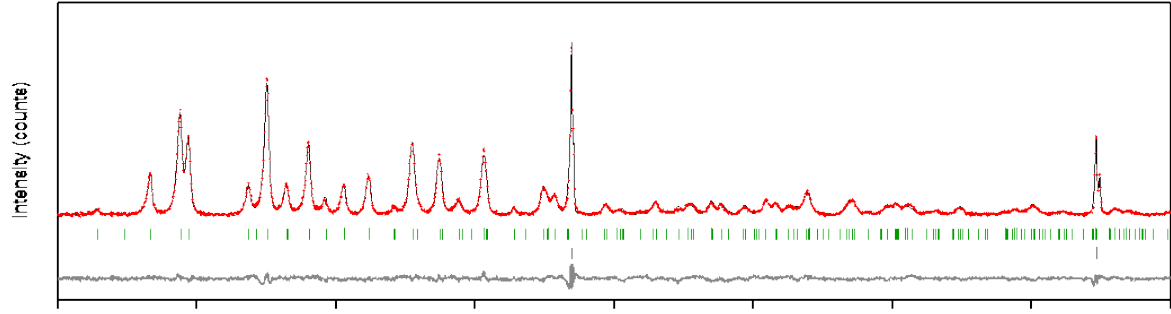

4

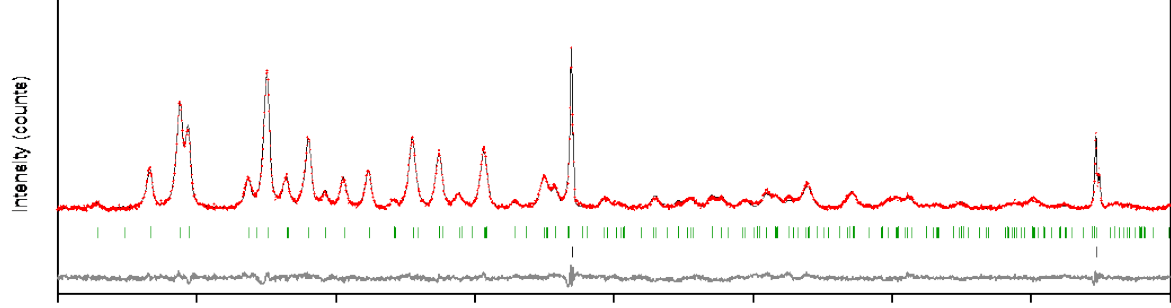

5

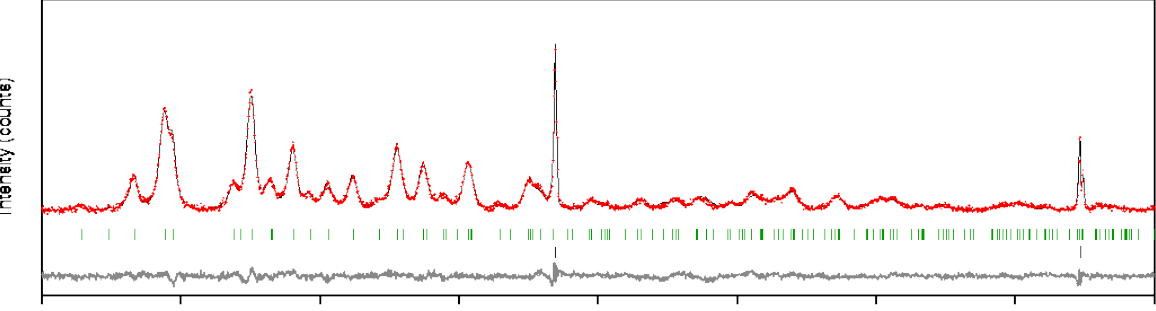

6

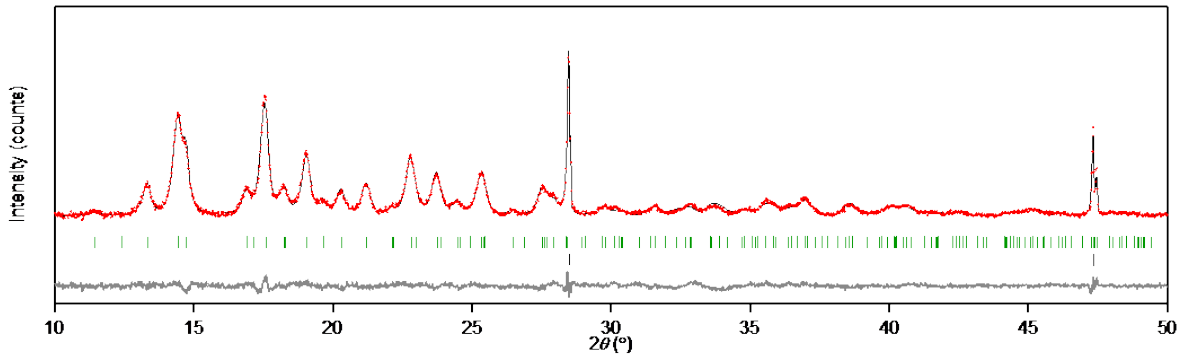

Figure 1. XRD patterns with Rietveld analyses of 1-6. Red plots, black lines, blue lines, green bars, and black bars are the observed patterns, calculated patterns, residue between the calculated and observed patterns, calculated positions of the Bragg reflections in the sample, and those of the silicon ( $\mathrm{Si}$ ) standard, respectively. The XRD peaks due to $\mathrm{Si}$ are shown as black sticks. Representative reflection indexes are shown in the XRD pattern of 1 . 


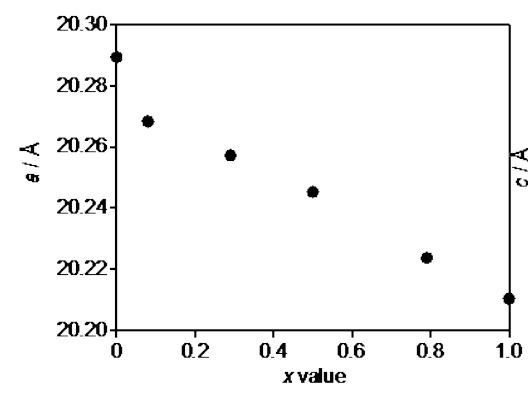

(a)

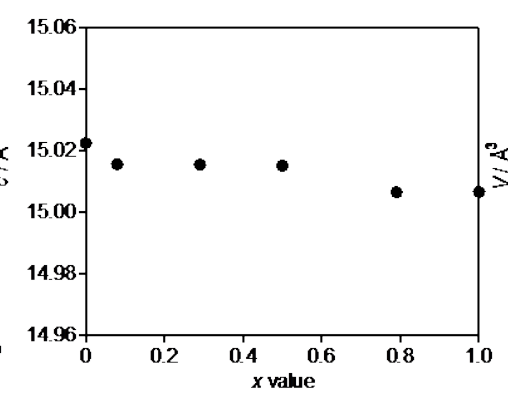

(b)

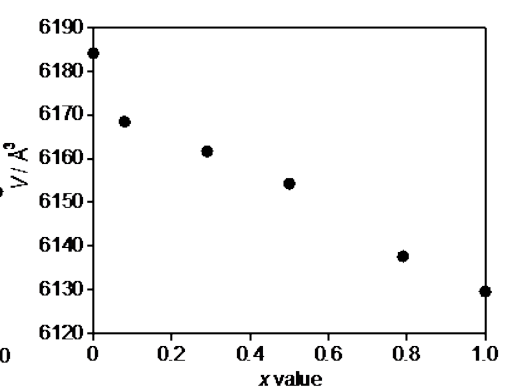

(c)

Figure 2. $x$ dependence of (a) the $a$-axis; (b) the c-axis; and, (c) the unit cell volume $(V)$.

The crystal structure and coordination geometries of this series are explained using 3 as an example. 3 has a tetragonal crystal structure in the $I 4_{1} / a$ space group with $a=20.2572(6) \AA$ and $c=15.0154(6) \AA$. The asymmetric unit is composed of a quarter of the $\left[\mathrm{Nb}(\mathrm{CN})_{8}\right]$ anion, half of the $\left[M(4 \text {-pyridinealdoxime })_{4}\right](M=\mathrm{Fe}$ or $\mathrm{Co})$ cation, and a water molecule. Here, we assume that $\mathrm{Fe}$ and $\mathrm{Co}$ are randomly incorporated. The coordination geometries of the $\mathrm{Nb}$ and $M$ sites are dodecahedron $\left(D_{2 \mathrm{~d}}\right)$ and pseudo-octahedron $\left(D_{4 \mathrm{~h}}\right)$, respectively. For the eight $\mathrm{CN}$ groups of $\mathrm{Nb}(\mathrm{CN})_{8}$, four $\mathrm{CN}$ groups are bridged to the $M$ ions, and the other four $\mathrm{CN}$ groups are not bridged. Two cyanide nitrogen atoms coordinate to the two axial positions of the $M$ site and four pyridyl nitrogen atoms of 4-pyridinealdoxime are located at the other four equatorial positions. A cyanido-bridged three-dimensional (3D) network structure is formed by the $\mathrm{M}-\mathrm{NC}-\mathrm{Nb}$ component (Figure 3).

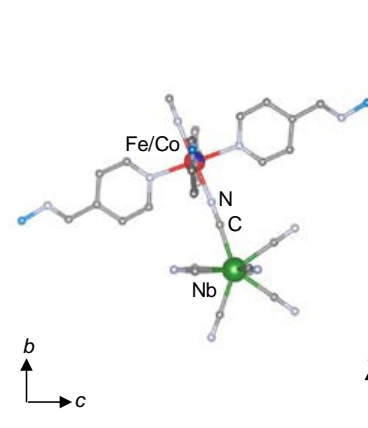

(a)

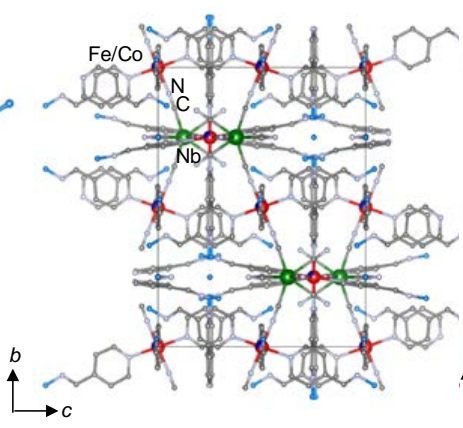

(b)

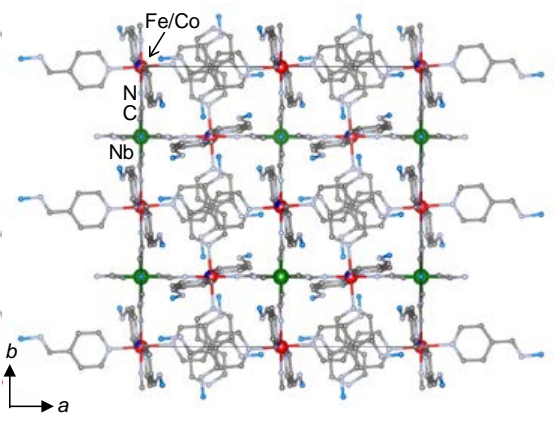

(c)

Figure 3. Crystal structure and coordination geometries around the metal centers for 3. (a) Coordination geometry around the metal centers; (b) crystal structure viewed from the $a$-axis; and, (c) from the $c$-axis. Water molecules are omitted for clarity.

The infrared spectrum of 1 shows two $C N$ stretching peaks at $2130 \mathrm{~cm}^{-1}$ and $2151 \mathrm{~cm}^{-1}$, which are ascribed to the $\mathrm{CN}$ stretching peak due to non-bridged $\mathrm{CN}(\mathrm{Nb}-\mathrm{CN})$ and bridged $\mathrm{CN}$ between $\mathrm{Nb}$ and $\mathrm{Fe}(\mathrm{Nb}-\mathrm{CN}-\mathrm{Fe})$, respectively. In 2-6, a different peak is observed around $2160 \mathrm{~cm}^{-1}$, and its intensity increases with an increasing $\mathrm{Co}^{\mathrm{II}}$ concentration, while the peak around $2151 \mathrm{~cm}^{-1}$ decreases. This indicates that the peak around $2160 \mathrm{~cm}^{-1}$ is due to the bridged $\mathrm{CN}$ between $\mathrm{Nb}$ and $\mathrm{Co}(\mathrm{Nb}-\mathrm{CN}-\mathrm{Co})$ (Figure 4$)$. 
1

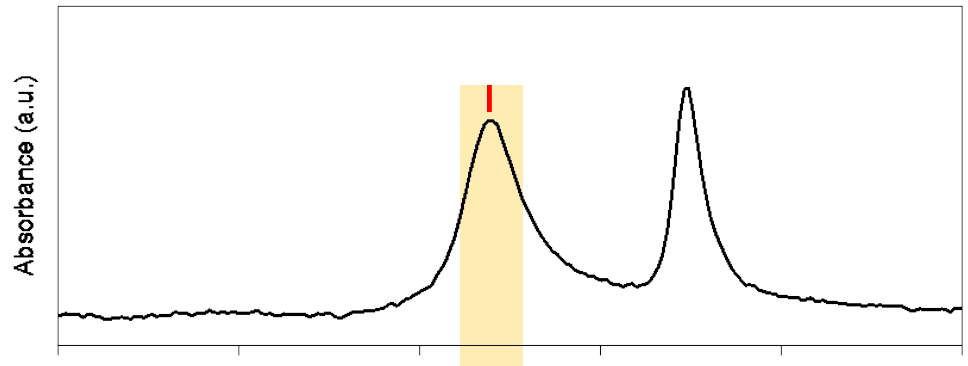

2

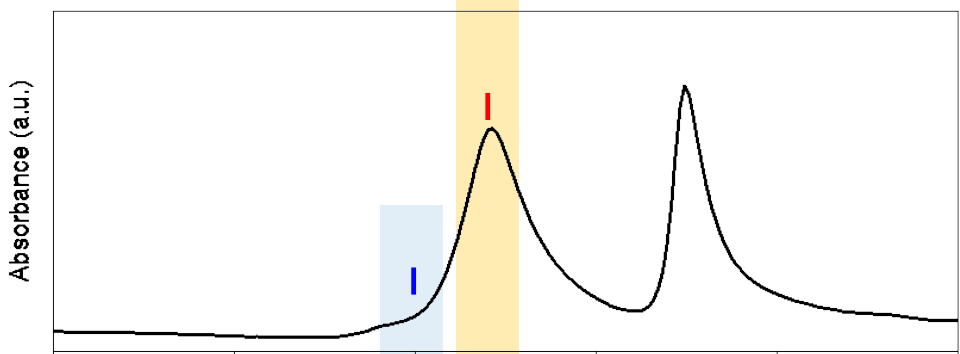

3

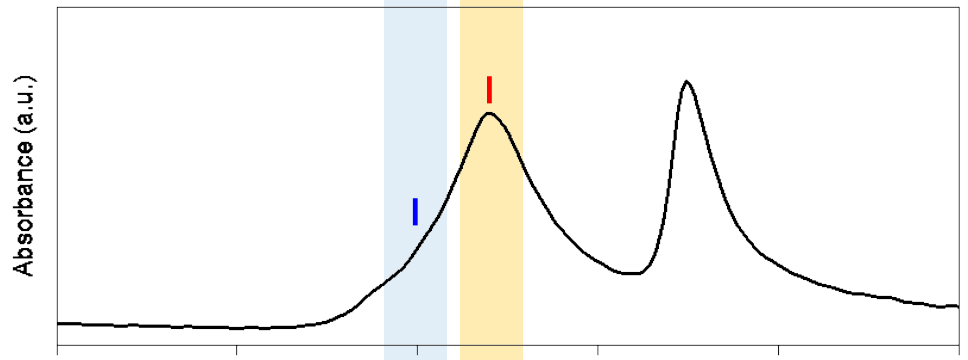

4

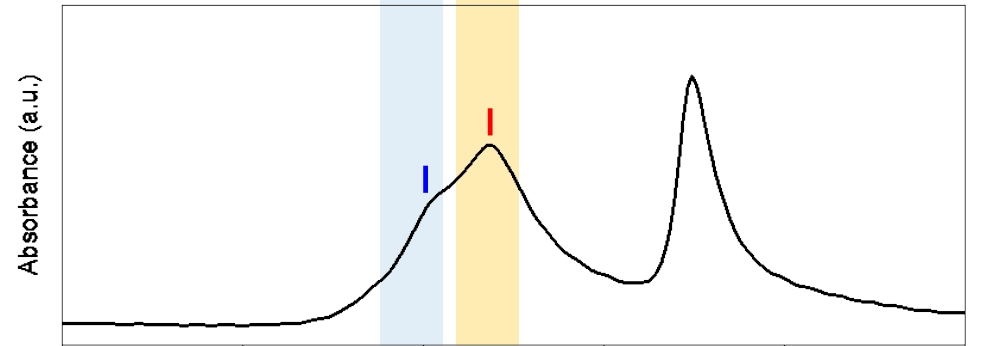

5

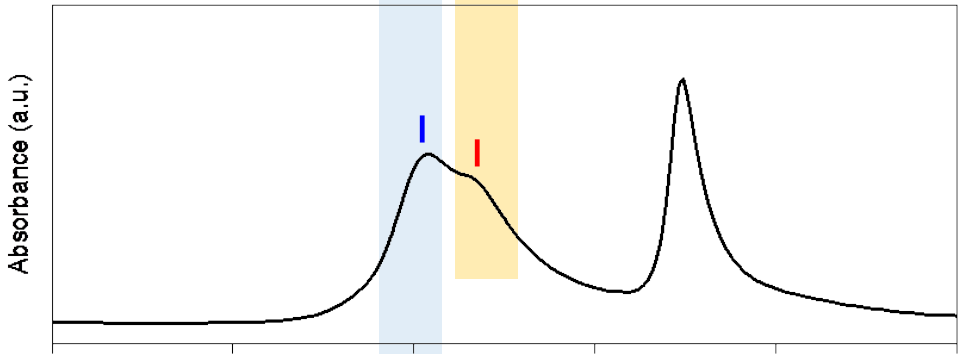

6

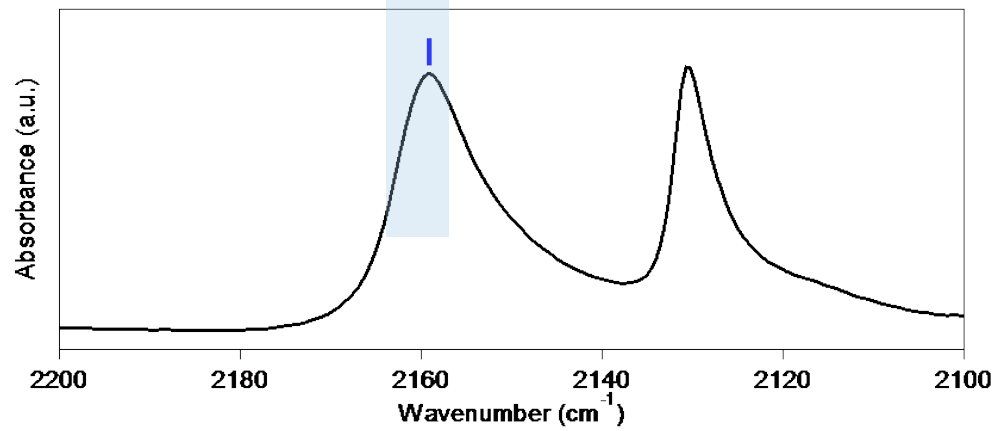

Figure 4. Infrared spectra of 1-6 at room temperature for the $\mathrm{CN}$ stretching region. 


\subsection{Magnetic Properties}

Figure 5 a shows the temperature dependence of the product of the magnetic susceptibility and the temperature $\left(\chi_{M} T\right)$ of 1-6 under an external magnetic field of 5000 Oe. The $\chi_{M} T$ values of 1-6 at $300 \mathrm{~K}$ are $7.04,7.08,6.77,6.11,5.79$, and $5.16 \mathrm{~K} \cdot \mathrm{cm}^{3} \cdot \mathrm{mol}^{-1}$, respectively. These values agree with the estimated values of $6.96,6.83,6.48,6.14,5.79$, and $5.16 \mathrm{~K} \cdot \mathrm{cm}^{3} \cdot \mathrm{mol}^{-1}$, which are obtained by Equation (1)

$$
\chi_{\mathrm{M}} T=\frac{N_{\mathrm{A}} \mu_{\mathrm{B}}^{2}}{3 k_{\mathrm{B}}}\left\{2 x g_{\mathrm{Co}}{ }^{2} S_{\mathrm{Co}}\left(S_{\mathrm{Co}}+1\right)+2(1-x) g_{\mathrm{Fe}}{ }^{2} S_{\mathrm{Fe}}\left(S_{\mathrm{Fe}}+1\right)+g_{\mathrm{Nb}}{ }^{2} S_{\mathrm{Nb}}\left(S_{\mathrm{Nb}}+1\right)\right\}
$$

where $N_{\mathrm{A}}$ is Avogadro's constant, $\mu_{\mathrm{B}}$ is the Bohr magneton, $k_{\mathrm{B}}$ is the Boltzmann constant, $g_{i}$ is the $g$ value of atom $i, S_{i}$ is the spin quantum number of atom $i$, and $x$ is the Co content $[53,54]$, assuming $g_{\mathrm{Fe}}=2.1, g_{\mathrm{Co}}=2.4, g_{\mathrm{Nb}}=2.0, S_{\mathrm{Fe}}=2, S_{\mathrm{Co}}=3 / 2$, and $S_{\mathrm{Nb}}=1 / 2$.

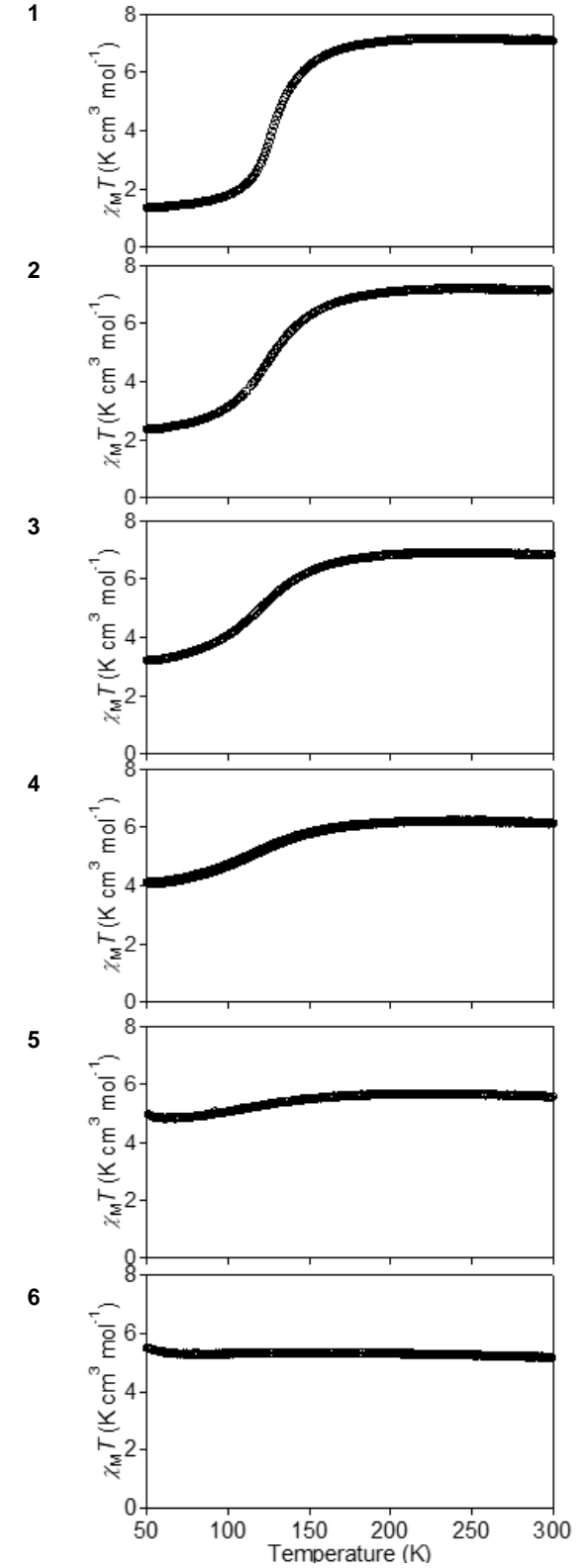

(a)

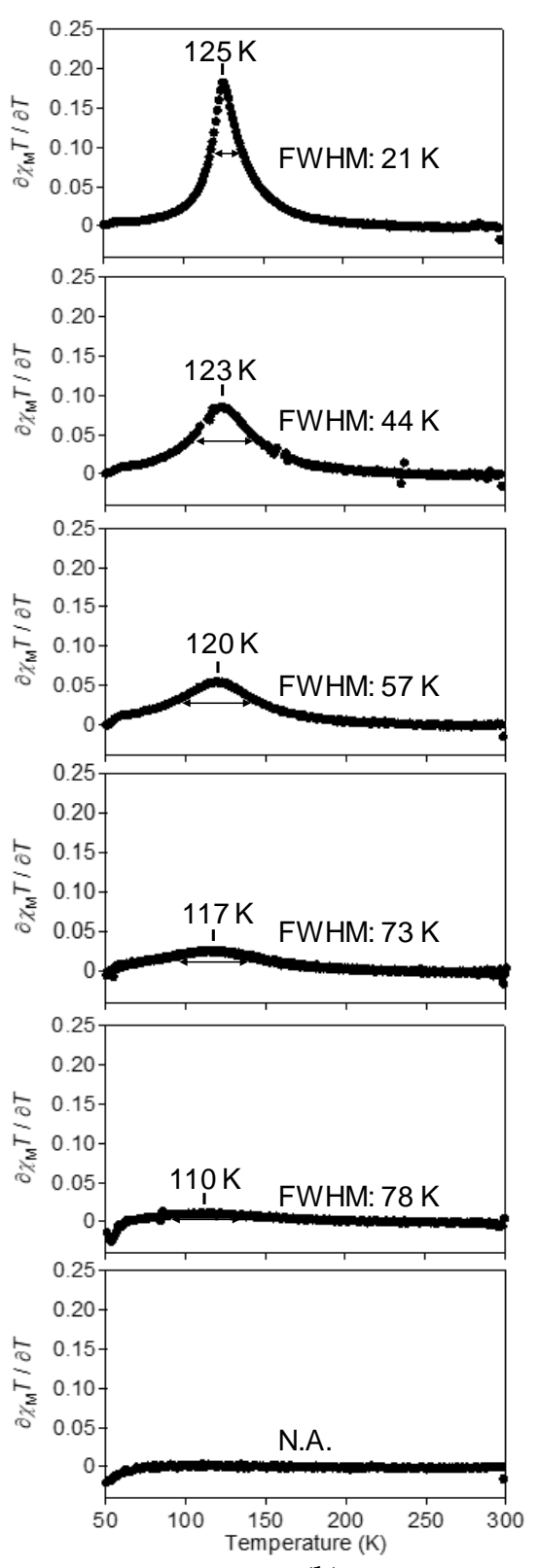

(b)

Figure 5. $\chi_{\mathrm{M}} T$ vs. $T$ plots $(\mathbf{a})$ and $\partial\left(\chi_{\mathrm{M}} T\right) / \partial T$ vs. $T$ plots $(\mathbf{b})$ of 1-6. 
As the temperature decreases, the $\chi_{\mathrm{M}} T$ values decreases at intermediate temperatures in 1-5, while the $\chi_{\mathrm{M}} T$ value of 6 is almost constant between $50 \mathrm{~K}$ and $300 \mathrm{~K}$. Thus, the occurrence of the $\mathrm{Fe}^{\mathrm{II}}$ spin-crossover phenomenon for all of the $\mathrm{Fe}^{\mathrm{II}}$ containing compounds is confirmed by the magnetic susceptibility measurements. The thermal spin-crossover temperature $\left(T_{1 / 2}\right)$, which is estimated as the temperature where the temperature differential of $\chi_{\mathrm{M}} T$ is maximized, shows that with an increasing $x$ value, $T_{1 / 2}$ shifts to a lower temperature (Figure $5 \mathrm{~b}$ and Figure S2). In addition, with an increasing $x$ value, spin crossovers become more gradual. According to the reported observations [16-25], these results are explained as follows. Since the ionic radii of $\mathrm{Co}(\mathrm{II})_{\mathrm{HS}}(0.75 \AA)$ is closer to $\mathrm{Fe}(\mathrm{III})_{\mathrm{HS}}$ $(0.78 \AA)$ than $\mathrm{Fe}(\mathrm{II})_{\mathrm{LS}}\left(0.61 \AA\right.$ ) [55], the spin-crossover from $\mathrm{Fe}(\mathrm{II})_{\mathrm{HS}}$ to $\mathrm{Fe}(\mathrm{II})_{\mathrm{LS}}$ becomes unfavorable, leading to a decrease of the spin transition temperature. Additionally, because the distance between spin-crossover sites becomes longer by metal substitution, the cooperativity between spin-crossover sites decreases, resulting in a gradual spin-crossover behavior.

Next, we measured the magnetic properties in the low temperature region. Figure 6a shows the magnetization vs. temperature plots of 1-6 with cooling temperature at an external magnetic field of 10 Oe. The magnetization vs. temperature curves of 2 and $\mathbf{3}$ show a small shoulder below 15 K. 4, 5, and 6 clearly show spontaneous magnetization with critical temperatures $\left(T_{\mathrm{c}}\right)$ of $8 \mathrm{~K}, 12 \mathrm{~K}$, and $18 \mathrm{~K}$, respectively. The magnetization vs. external magnetic field plots at $2 \mathrm{~K}$ show that the magnetic coercive fields of 4, 5, and 6 are 1400 Oe, 3100 Oe, and 13,000 Oe, respectively (Figure 6b). The singleness of the $T_{\mathrm{C}}$ values and the shape of magnetic hysteresis loop indicate that $\mathrm{Fe}$ and $\mathrm{Co}$ are mixed with each other on the atomic level. The observation of such a large coercive field is attributed to the single-ion anisotropy of Co ion possessing an unquenched orbital angular momentum.
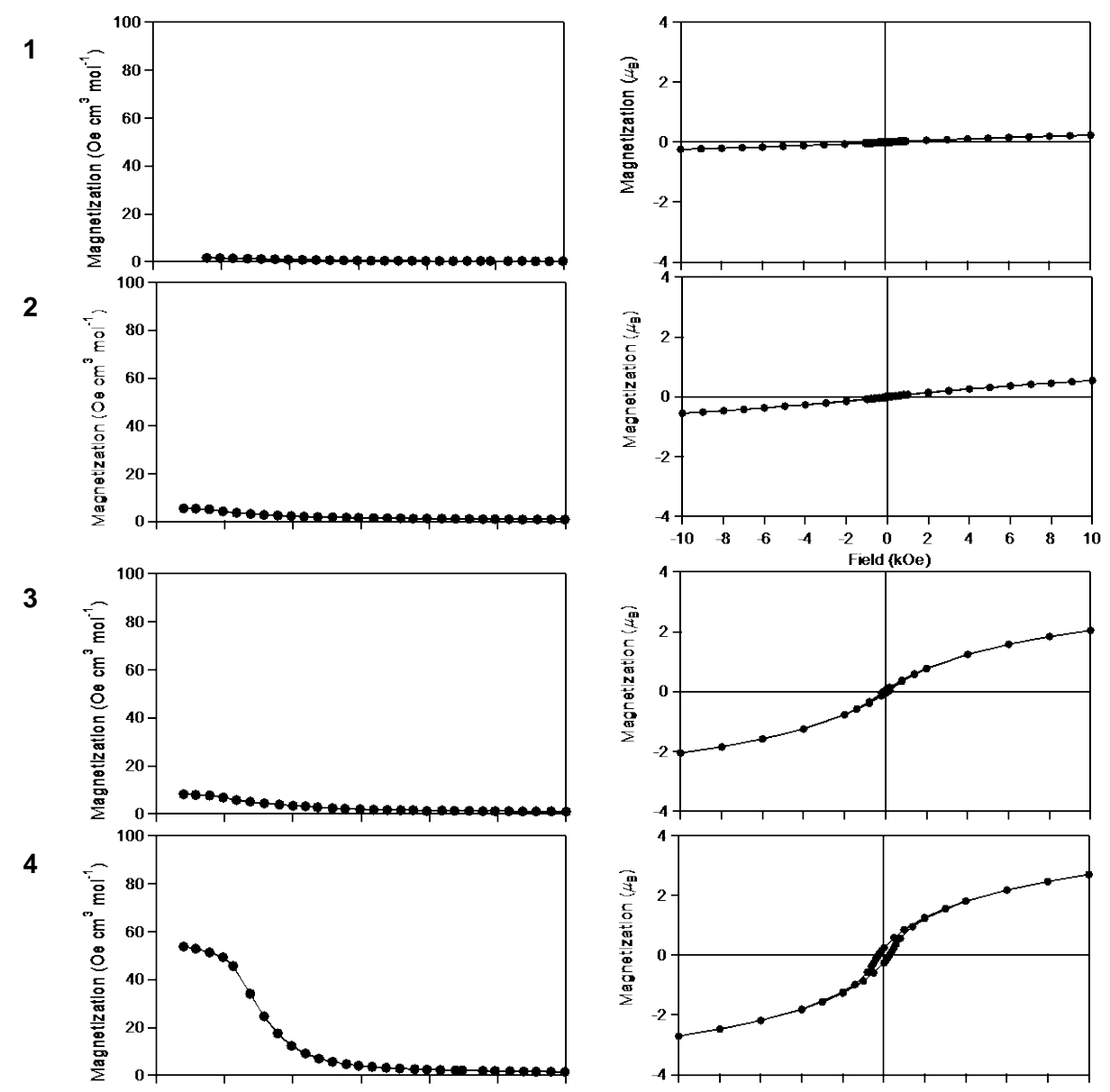

Figure 6. Cont. 


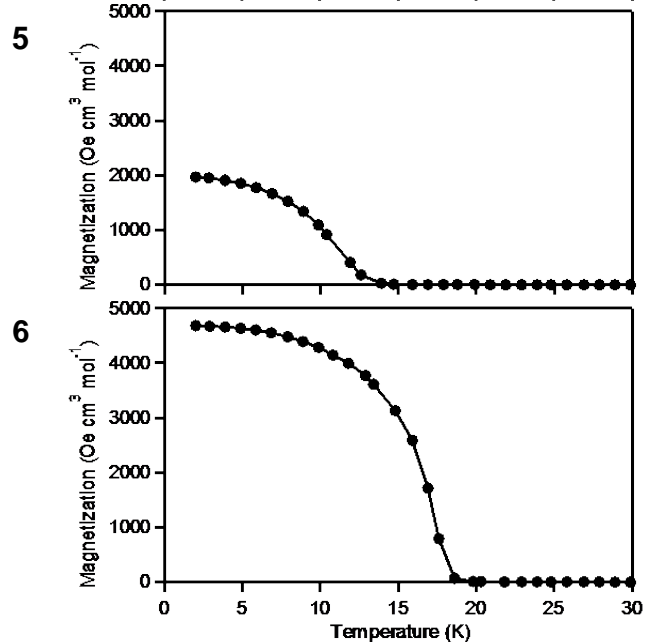

(a)

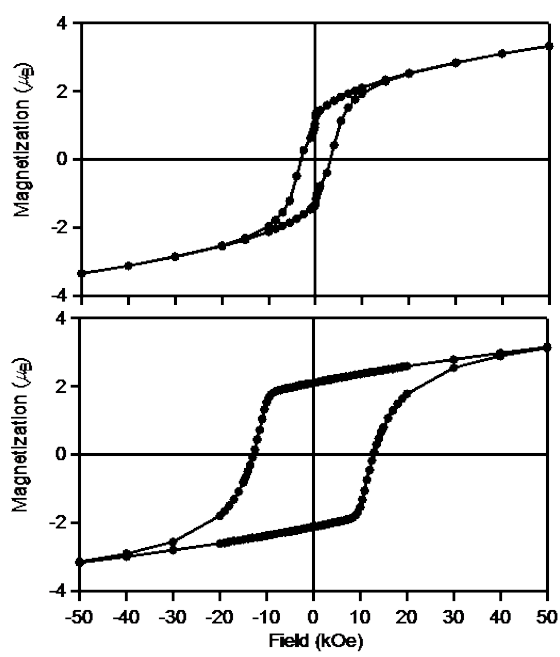

(b)

Figure 6. (a) Magnetization vs. temperature plots and (b) magnetization vs. external magnetic field plots of 1-6.

\section{Materials and Methods}

\subsection{Syntheses}

$\mathrm{K}_{4}\left[\mathrm{Nb}(\mathrm{CN})_{8}\right] \cdot 2 \mathrm{H}_{2} \mathrm{O}$ was synthesized according to the reported procedure [56]. Other reagents were purchased from commercial sources (Wako Pure Chemical Industries and Tokyo Chemical Industries) and were used without further purification. For the preparation of $\left(\mathrm{Fe}_{x} \mathrm{Co}_{1-x}\right)_{2}\left[\mathrm{Nb}(\mathrm{CN})_{8}\right](4 \text {-pyridinealdoxime })_{8} \cdot \mathrm{zH}_{2} \mathrm{O}$, a 98- $\mathrm{cm}^{3}$ aqueous solution containing $\mathrm{FeCl}_{2} \cdot 4 \mathrm{H}_{2} \mathrm{O}$ and $\mathrm{CoCl}_{2} \cdot 6 \mathrm{H}_{2} \mathrm{O}(0.2 \mathrm{mmol}$ in total), $\mathrm{L}-(+)$-ascorbic acid $(0.4 \mathrm{mmol})$, and 4-pyridinealdoxime $(4 \mathrm{mmol})$, was added to an aqueous solution $\left(2 \mathrm{~cm}^{3}\right)$ of $\mathrm{K}_{4}\left[\mathrm{Nb}(\mathrm{CN})_{8}\right] \cdot 2 \mathrm{H}_{2} \mathrm{O}(0.1 \mathrm{mmol})$ with $\mathrm{Fe} / \mathrm{Co}$ ratios $[\mathrm{Fe}] /([\mathrm{Fe}]+[\mathrm{Co}])$ of $0,0.1,0.25,0.5,0.75$, and 1 , yielding a microcrystalline powder. Stirring was continued for $1 \mathrm{~h}$. Then the solution was filtered and washed twice by water. Elemental analyses indicate that the chemical formulae of the obtained compounds were $\mathrm{Fe}_{2}\left[\mathrm{Nb}(\mathrm{CN})_{8}\right](4 \text {-pyridinealdoxime })_{8} \cdot 3 \mathrm{H}_{2} \mathrm{O}(\mathbf{1}),\left(\mathrm{Fe}_{0.92} \mathrm{Co}_{0.08}\right)_{2}\left[\mathrm{Nb}(\mathrm{CN})_{8}\right](4 \text {-pyridinealdoxime })_{8} \cdot 3 \mathrm{H}_{2} \mathrm{O}(2)$, $\left(\mathrm{Fe}_{0.71} \mathrm{Co}_{0.29}\right)_{2}\left[\mathrm{Nb}(\mathrm{CN})_{8}\right]$ (4-pyridinealdoxime $)_{8} \cdot 3 \mathrm{H}_{2} \mathrm{O}(3),\left(\mathrm{Fe}_{0.50} \mathrm{Co}_{0.50}\right)_{2}\left[\mathrm{Nb}(\mathrm{CN})_{8}\right]$ (4-pyridinealdoxime $)_{8}$ $\cdot 3 \mathrm{H}_{2} \mathrm{O}(4),\left(\mathrm{Fe}_{0.21} \mathrm{Co}_{0.79}\right)_{2}\left[\mathrm{Nb}(\mathrm{CN})_{8}\right](4 \text {-pyridinealdoxime })_{8} \cdot 3 \mathrm{H}_{2} \mathrm{O}(5)$, and $\mathrm{Co}_{2}\left[\mathrm{Nb}(\mathrm{CN})_{8}\right](4 \text {-pyridinealdoxime })_{8}$ .3 $\mathrm{H}_{2} \mathrm{O}$ (6). Calcd. for 1: Fe, 7.74; Nb, 6.43; C, 46.59; H, 3.77; N, 23.28. Found for 1: Fe, 7.98; Nb, 6.69; C, 46.71; H, 3.72; N, 23.39. Calcd. for 2: Fe, 7.11; Co, 0.65; Nb, 6.43; C, 46.57; H, 3.77; N, 23.28. Found for 2: $\mathrm{Fe}, 7.07 ; \mathrm{Co}, 0.67 ; \mathrm{Nb}, 6.40 ; \mathrm{C}, 46.57 ; \mathrm{H}, 3.66 ; \mathrm{N}, 23.33$. Calcd. for 3: Fe, 5.49; Co, 2.36; Nb, 6.43; C, 46.53; $\mathrm{H}, 3.77 ; \mathrm{N}, 23.25$. Found for 3: Fe, 5.68; Co, 2.45; Nb, 6.44; C, 46.44; H, 3.69; N, 23.39. Calcd. for 4: Fe, 3.86; Co, 4.07; Nb, 6.42; C, 46.49; H, 3.76; N, 23.23. Found for 4: Fe, 3.81; Co, 4.13; Nb, 6.32; C, 46.40; H, 3.69; N, 23.39. Calcd. for 5: Fe, 1.62; Co, 6.42; Nb, 6.41; C, 46.43; H, 3.76; N, 23.20. Found for 5: Fe, 1.56; $\mathrm{Co}, 6.47 ; \mathrm{Nb}, 6.39 ; \mathrm{C}, 46.71 ; \mathrm{H}, 3.71 ; \mathrm{N}, 23.12$. Calcd. for 6: Co, 8.13; Nb, 6.41; C, 46.39; H, 3.75; N, 23.18. Found for 6 : $\mathrm{Co}, 8.26 ; \mathrm{Nb}, 6.54 ; \mathrm{C}, 46.37 ; \mathrm{H}, 3.71 ; \mathrm{N}, 23.18$.

\subsection{Measurements}

Elemental analyses for $\mathrm{C}, \mathrm{H}$, and $\mathrm{N}$ were carried out by standard microanalytical methods while those for $\mathrm{Fe}, \mathrm{Co}$, and $\mathrm{Nb}$ were analyzed by inductive plasma mass spectroscopy. FT-IR spectra were recorded on a FT-IR4100 spectrometer (JASCO, Tokyo, Japan). X-ray powder diffraction was measured on a Ultima-IV powder diffractometer (Rigaku, Tokyo, Japan). Rietveld analyses were performed using PDXL program (Rigaku, Tokyo, Japan). Magnetic susceptibility and magnetization measurements 
were carried out using a MPMS superconducting quantum interference device (SQUID) magnetometer (Quantum Design, San Diego, CA, USA).

\section{Conclusions}

In this work, we synthesized and characterized ternary metal cyanido-bridged metal assemblies of $\left(\mathrm{Fe}_{x} \mathrm{Co}_{1-\mathrm{x}}\right)_{2}\left[\mathrm{Nb}(\mathrm{CN})_{8}\right](4 \text {-pyridinealdoxime })_{8} \cdot z \mathrm{H}_{2} \mathrm{O}$. The magnetic measurements reveal that all of the Fe-containing systems present a spin-crossover phenomenon. In particular, $\left(\mathrm{Fe}_{0.21} \mathrm{Co}_{0.79}\right)_{2}\left[\mathrm{Nb}(\mathrm{CN})_{8}\right](4 \text {-pyridinealdoxime })_{8} \cdot z \mathrm{H}_{2} \mathrm{O}$ exhibits a coexistence of a spin-crossover phenomenon and a magnetic phase transition with $T_{\mathrm{c}}$ of $12 \mathrm{~K}$ and a large $H_{\mathrm{c}}$ of $3100 \mathrm{Oe}$. Additional investigations on the photomagnetic effect are in progress.

Supplementary Materials: The following are available online at www.mdpi.com/2304-6740/5/4/63/s1. Cif and cif-checked files of 1-6. Figure S1: SEM images and particle size distributions of 1-6; Figure S2: Co fraction $(x)$ dependence of spin-crossover transition temperature of 1-5.

Acknowledgments: The present research was supported in part by a JSPS Grant-in-Aid for specially promoted Research (Grant Number 15H05697). We also recognize the Cryogenic Research Center, The University of Tokyo, and Nanotechnology Platform, which are supported by MEXT.

Author Contributions: Shin-ichi Ohkoshi conceived and designed the project. Kenta Imoto and Shinjiro Takano performed the experiments. Kenta Imoto and Shinjiro Takano analyzed the data. Shin-ichi Ohkoshi and Kenta Imoto wrote the paper.

Conflicts of Interest: The authors declare no conflict of interest.

\section{References}

1. Gütlich, P.; Goodwin, H.A. Spin Crossover in Transition Metal Compounds; Springer: New York, NY, USA, 2004.

2. Halcrow, M.A. Spin Crossover Materials: Properties and Applications; John Wiley \& Sons: Chichester, UK, 2013.

3. Gütlich, P.; Hauser, A.; Spiering, H. Thermal and Optical Switching of Iron (II) Complexes. Angew. Chem. Int. Ed. Engl. 1994, 33, 2024-2054. [CrossRef]

4. Decurtins, S.; Gütlich, P.; Köhler, C.P.; Spiering, H.; Hauser, A. Light-induced excited spin state trapping in a transition-metal complex: The hexa-1-propyltetrazole-iron (II) tetrafluoroborate spin-crossover system. Chem. Phys. Lett. 1984, 105, 1-4. [CrossRef]

5. Hauser, A. Intersystem Crossing in Fe(II) Coordination Compounds. Coord. Chem. Rev. 1991, 111, $275-290$. [CrossRef]

6. Real, J.A.; Andres, E.; Munoz, M.C.; Julve, M.; Granier, T.; Bousseksou, A.; Varret, F. Spin Crossover in a Catenan Supramolecular System. Science 1995, 268, 265-267. [CrossRef] [PubMed]

7. Halder, G.J.; Kepert, C.J.; Moubaraki, B.; Murray, K.S.; Cashion, J.D. Guest-dependent spin crossover in a nanoporous molecular framework material. Science 2002, 298, 1762-1765. [CrossRef] [PubMed]

8. Renz, F.; Oshio, H.; Ksenofontov, V.; Waldeck, M.; Spiering, H.; Gütlich, P. Strong field iron (II) complex converted by light into a long-lived high-spin state. Angew. Chem. Int. Ed. 2000, 39, 3699-3700. [CrossRef]

9. Gaspar, A.B.; Seredyuk, M.; Gütlich, P. Spin crossover in metallomesogens. Coord. Chem. Rev. 2009, 253, 2399-2413. [CrossRef]

10. Ould Moussa, N.; Molnar, G.; Bonhommeau, S.; Zwick, A.; Mouri, S.; Tanaka, K.; Real, J.A.; Bousseksou, A. Selective Photoswitching of the Binuclear Spin Crossover Compound $\left\{\left[\mathrm{Fe}(\mathrm{bt})(\mathrm{NCS})_{2}\right]_{2}(\mathrm{bpm})\right\}$ into Two Distinct Macroscopic Phases. Phys. Rev. Lett. 2005, 94, 107205. [CrossRef] [PubMed]

11. Papanikolaou, D.; Margadonna, S.; Kosaka, W.; Ohkoshi, S.; Brunelli, M.; Prassides, K. X-ray Illumination Induced Fe(II) Spin Crossover in the Prussian Blue Analogue Cesium Iron Hexacyanochromate. J. Am. Chem. Soc. 2006, 128, 8358-8363. [CrossRef] [PubMed]

12. Bertoni, R.; Cammarata, M.; Lorenc, M.; Matar, S.; Létard, J.-F.; Lemke, H.-T.; Collet, E. Ultrafast Light-Induced Spin-State Trapping Photophysics Investigated in Fe(phen $)_{2}(\mathrm{NCS})_{2}$ Spin-Crossover Crystal. Acc. Chem. Res. 2015, 48, 774-781. [CrossRef] [PubMed]

13. Trzop, E.; Zhang, D.; Pineiro-Lopez, L.; Valvarde-Munoz, F.J.; Munoz, M.C.; Palatinus, L.; Guerin, L.; Cailleau, H.; Real, J.A.; Collet, E. First Step towards a Devil's Staircase in Spin-Crossover Materials. Angew. Chem. Int. Ed. 2016, 55, 8675-8679. [CrossRef] [PubMed] 
14. Kahn, O.; Martinez, C.J. Spin-transition polymers: From molecular materials toward memory devices. Science 1998, 279, 44-48. [CrossRef]

15. Molnar, G.; Salmon, L.; Nicolazzi, W.; Terki, F.; Bousseksou, A. Emerging properties and applications of spin crossover nanomaterials. J. Mater. Chem. C 2014, 2, 1360-1366. [CrossRef]

16. Gütlich, P.; Link, R.; Steinhäuser, H. Mössbauer-Effect Study of the Thermally Induced Spin Transition in Tris(2-picolylamine)iron(II) Chloride. Dilution Effect in Mixed Crystals of $\left[\mathrm{Fe}_{x} \mathrm{Zn}_{1-x}(2-\text { pic })_{3}\right] \mathrm{Cl}_{2} \cdot \mathrm{C}_{2} \mathrm{H}_{5} \mathrm{OH}$ $(x=0.15,0.0029,0.0009)$. Inorg. Chem. 1978, 9, 2509-2514. [CrossRef]

17. Ganguli, P.; Gütlich, P.; Müller, E.W. Effect of metal dilution on the spin-crossover behavior in $\left.\left[\mathrm{Fe}_{x} \mathrm{M}_{1-x} \text { (phen) }\right)_{2}(\mathrm{NCS})_{2}\right](\mathrm{M}=\mathrm{Mn}, \mathrm{Co}, \mathrm{Ni}, \mathrm{Zn})$. Inorg. Chem. 1982, 21, 3429-3433. [CrossRef]

18. Haddad, M.S.; Federer, W.D.; Lynch, M.W.; Hendrickson, D.N. An explanation of unusual properties of spin-crossover ferric complexes. J. Am. Chem. Soc. 1980, 102, 1468-1470. [CrossRef]

19. Martin, J.-P.; Zarembowitch, J.; Bousseksou, A.; Dworkin, A.; Haasnoot, J.G.; Varret, F. Solid State Effects on Spin Transitions: Magnetic, Calorimetric, and Mössbauer-Effect Properties of $\left[\mathrm{Fe}_{x} \mathrm{Co}_{1-x}\left(4,4^{\prime} \text {-bis-1,2,4-triazole }\right)_{2}(\mathrm{NCS})_{2}\right] \cdot \mathrm{H}_{2} \mathrm{O}$ Mixed-Crystal Compounds. Inorg. Chem. 1994, 33, 6325-6333. [CrossRef]

20. Tayagaki, T.; Galet, A.; Molnar, G.; Munoz, M.C.; Zwick, A.; Tanaka, K.; Real, J.A.; Bousseksou, A. Metal Dilution Effects on the Spin-Crossover Properties of the Three-Dimensional Coordination Polymer Fe(pyrazine) $\left[\mathrm{Pt}(\mathrm{CN})_{4}\right]$. J. Phys. Chem. B 2005, 109, 14859-14867. [CrossRef] [PubMed]

21. Krivokapic, I.; Chakraborty, P.; Enachescu, C.; Bronisz, R.; Hauser, A. Low-Spin $\rightarrow$ High-Spin Relaxation Dynamics in the Highly Diluted Spin-Crossover System $\left[\mathrm{Fe}_{x} \mathrm{Zn}_{1-x}(\mathrm{bbtr})_{3}\right]\left(\mathrm{ClO}_{4}\right)_{2}$. Inorg. Chem. 2011, 50, 1856-1861. [CrossRef] [PubMed]

22. Chakraborty, P.; Enachescu, C.; Walder, C.; Bronisz, R.; Hauser, A. Thermal and Light-Induced Spin Switching Dynamics in the 2D Coordination Network of $\left\{\left[\mathrm{Zn}_{1-x} \mathrm{Fe}_{x}(\mathrm{bbtr})_{3}\right]\left(\mathrm{ClO}_{4}\right)_{2}\right\}_{\infty}$ : The Role of Cooperative Effects. Inorg. Chem. 2012, 51, 9714-9722. [CrossRef] [PubMed]

23. Zheng, S.; Siegler, M.-A.; Costa, J.-S.; Fu, W.-T.; Bonnet, S. Effect of Metal Dilution on the Thermal Spin Transition of [Fe $\mathrm{Zn}_{1-x}$ (bapbpy)(NCS) $)_{2}$. Eur. J. Inorg. Chem. 2013, 2013, 1033-1042. [CrossRef]

24. Paradis, N.; Chastanet, G.; Palamarciuc, T.; Rosa, P.; Varret, F.; Boukheddaden, K.; Létard, J.-F. Detailed Investigation of the Interplay Between the Thermal Decay of the Low Temperature Metastable HS State and the Thermal Hysteresis of Spin-Crossover Solids. J. Phys. Chem. C 2015, 119, 20039-20050. [CrossRef]

25. Baldé, C.; Desplanches, C.; Létard, J.-F.; Chastanet, G. Effects of metal dilution on the spin-crossover behavior and light induced bistability of iron(II) in [ $\left.\mathrm{Fe}_{x} \mathrm{Ni}_{1-x}(\mathrm{bpp})_{2}\right](\mathrm{NCSe})_{2}$. Polyhedron 2017, 123, 138-144. [CrossRef]

26. Kahn, O.; Gatteschi, D.; Miller, J.S.; Palacio, F. NATO ARW Molecular Magnetic Materials; Kluwer Academic Publishers: London, UK, 1991.

27. Dunbar, K.R.; Heintz, R.A. Chemistry of Transition Metal Cyanide Compounds: Modern Perspectives. Prog. Inorg. Chem. 1997, 45, 283-391. [CrossRef]

28. Miller, J.S.; Drillon, M. Magnetism-Molecules to Materials; Wilely-VCH: Weinheim, Germany, 2005.

29. Train, C.; Gruselle, M.; Verdaguer, M. The fruitful introduction of chirality and control of absolute configurations in molecular magnets. Chem. Soc. Rev. 2011, 40, 3297-3312. [CrossRef] [PubMed]

30. Ohkoshi, S.; Tokoro, H. Photomagnetism in Cyano-Bridged Bimetal Assemblies. Acc. Chem. Res. 2012, 45, 1749-1758. [CrossRef] [PubMed]

31. Ferlay, S.; Mallah, T.; Ouahès, R.; Veillet, P.; Verdaguer, M. A room-temperature organometallic magnet based on Prussian blue. Nature 1995, 378, 701-703. [CrossRef]

32. Hatlevik, Ø.; Buschmann, W.E.; Zhang, J.; Manson, J.L.; Miller, J.S. Enhancement of the Magnetic Ordering Temperature and Air Stability of a Mixed Valent Vanadium Hexacyanochromate(III) Magnet to $99{ }^{\circ} \mathrm{C}(372 \mathrm{~K})$. Adv. Mater. 1999, 11, 914-918. [CrossRef]

33. Holmes, S.M.; Girolami, G.S. Sol-Gel Synthesis of $\mathrm{KV}^{\mathrm{II}}\left[\mathrm{Cr}^{\mathrm{III}}(\mathrm{CN})_{6}\right] \cdot 2 \mathrm{H}_{2} \mathrm{O}$ : A Crystalline Molecule-Based Magnet with a Magnetic Ordering Temperature above $100{ }^{\circ} \mathrm{C}$. J. Am. Chem. Soc. 1999, 121, 5593-5594. [CrossRef]

34. Ohkoshi, S.; Mizuno, M.; Hung, G.J.; Hashimoto, K. Magnetooptical Effects of Room Temperature Molecular-Based Magnetic Films Composed of Vanadium Hexacyanochromates. J. Phys. Chem. B 2000, 104, 9365-9367. [CrossRef] 
35. Verdaguer, M.; Bleuzen, A.; Marvaud, V.; Vaissermann, J.; Seuleiman, M.; Desplanches, C.; Scuiller, A.; Train, C.; Garde, R.; Gelly, G.; et al. Molecules to build solids: High $T_{C}$ molecule-based magnets by design and recent revival of cyano complexes chemistry. Coord. Chem. Rev. 1999, 190, 1023-1047. [CrossRef]

36. Ohkoshi, S.; Einaga, Y.; Fujishima, A.; Hashimoto, K. Magnetic properties and optical control of electrochemically prepared iron-chromium polycyanides. J. Electroanal. Chem. 1999, 473, 245-249. [CrossRef]

37. Herrera, J.M.; Marvaud, V.; Verdaguer, M.; Marrot, J.; Kalisz, M.; Mathonière, C. Reversible Photoinduced Magnetic Properties in the Heptanuclear Complex $\left[\mathrm{Mo}^{\mathrm{IV}}(\mathrm{CN})_{2}(\mathrm{CN}-\mathrm{CuL})_{6}\right]^{8+}$ : A Photomagnetic High-Spin Molecule. Angew. Chem. Int. Ed. 2004, 43, 5468-5471. [CrossRef] [PubMed]

38. Ohkoshi, S.; Tokoro, H.; Hozumi, T.; Zhang, Y.; Hashimoto, K.; Mathonière, C.; Bord, I.; Rombaut, G.; Verelst, M.; Cartier dit Moulin, C.; et al. Photo-induced magnetization in copper octacyanomolybdate. J. Am. Chem. Soc. 2006, 128, 270-277. [CrossRef] [PubMed]

39. Mahfoud, T.; Molnar, G.; Bonhommeau, S.; Cobo, S.; Salmon, L.; Demont, P.; Tokoro, H.; Ohkoshi, S.; Boukheddaden, K.; Bousseksou, A. Electric-Field-Induced Charge-Transfer Phase Transition: A Promising Approach toward Electrically Switchable Devices. J. Am. Chem. Soc. 2009, 131, 15049-15054. [CrossRef] [PubMed]

40. Bleuzen, A.; Marvaud, V.; Mathonière, C.; Sieklucka, B.; Verdaguer, M. Photomagnetism in Clusters and Extended Molecule-Based Magnets. Inorg. Chem. 2009, 48, 3453-3466. [CrossRef] [PubMed]

41. Pajerowski, D.M.; Andrus, M.J.; Gardner, J.E.; Knowles, E.S.; Meisel, M.W.; Talham, D.R. Persistent Photoinduced Magnetism in Heterostructures of Prussian Blue Analogues. J. Am. Chem. Soc. 2010, 132, 4058-4059. [CrossRef] [PubMed]

42. Ozaki, N.; Tokoro, H.; Hamada, Y.; Namai, A.; Matsuda, T.; Kaneko, S.; Ohkoshi, S. Photoinduced magnetization with a high Curie temperature and a large coercive field in a Co-W bimetallic assembly. Adv. Funct. Mater. 2012, 20, 2089-2093. [CrossRef]

43. Ohkoshi, S.; Arimoto, Y.; Hozumi, T.; Seino, H.; Mizobe, Y.; Hashimoto, K. Two-dimensional metamagnet composed of cyano-bridged $\mathrm{Cu}^{\mathrm{II}}-\mathrm{W}^{\mathrm{V}}$ bimetallic assembly. Chem. Commun. 2003, 22, 2772-2773. [CrossRef]

44. Kato, K.; Moritomo, Y.; Takata, M.; Sakata, M.; Umekawa, M.; Hamada, N.; Ohkoshi, S.; Tokoro, H.; Hashimoto, K. Direct Observation of Charge Transfer in Double-Perovskite-Like $\operatorname{RbMn}\left[\mathrm{Fe}(\mathrm{CN})_{6}\right]$. Phys. Rev. Lett. 2003, 91, 255502. [CrossRef] [PubMed]

45. Tokoro, H.; Matsuda, T.; Nuida, T.; Moritomo, Y.; Ohoyama, K.; Dangui, E.D.L.; Boukheddaden, K.; Ohkoshi, S. Visible-light-induced reversible photomagnetism in rubidium manganese hexacyanoferrate. Chem. Mater. 2008, 20, 423-428. [CrossRef]

46. Vertelman, E.J.M.; Lummen, T.T.A.; Meetsma, A.; Bouwkamp, M.W.; Molnar, G.; Loosdrecht, P.H.M.; Koningsbruggen, P.J. Light- and Temperature-Induced Electron Transfer in Single Crystals of $\mathrm{RbMn}\left[\mathrm{Fe}(\mathrm{CN})_{6}\right] \cdot \mathrm{H}_{2} \mathrm{O}$. Chem. Mater. 2008, 20, 1236-1238. [CrossRef]

47. Tokoro, H.; Nakagawa, K.; Imoto, K.; Hakoe, F.; Ohkoshi, S. Zero thermal expansion fluid and oriented film based on a bistable metal-cyanide polymer. Chem. Mater. 2012, 24, 1324-1330. [CrossRef]

48. Kosaka, W.; Nomura, K.; Hashimoto, K.; Ohkoshi, S. Observation of an Fe(II) Spin-Crossover in a Cesium Iron Hexacyanochromate. J. Am. Chem. Soc. 2005, 127, 8590-8591. [CrossRef] [PubMed]

49. Arai, M.; Kosaka, W.; Matsuda, T.; Ohkoshi, S. Observation of an Iron(II) Spin-Crossover in an Iron Octacyanoniobate-Based Magnet. Angew. Chem. Int. Ed. 2008, 47, 6885-6887. [CrossRef] [PubMed]

50. Ohkoshi, S.; Imoto, K.; Tsunobuchi, Y.; Takano, S.; Tokoro, H. Light-induced spin-crossover magnet. Nat. Chem. 2011, 3, 564-569. [CrossRef] [PubMed]

51. Ohkoshi, S.; Takano, S.; Imoto, K.; Yoshikiyo, M.; Namai, A.; Tokoro, H. 90-degree optical switching of output second-harmonic light in chiral photomagnet. Nat. Photonics 2014, 8, 65-71. [CrossRef]

52. Imoto, K.; Takemura, M.; Nakabayashi, K.; Miyamoto, Y.; Orisaku, K.K.; Ohkoshi, S. Syntheses, crystal structures, and magnetic properties of $\mathrm{Mn}-\mathrm{Nb}$ and $\mathrm{Co}-\mathrm{Nb}$ cyanido-bridged bimetallic assemblies. Inorg. Chim. Acta 2015, 425, 92-99. [CrossRef]

53. Ohkoshi, S.; Iyoda, T.; Fujishima, A.; Hashimoto, K. Magnetic properties of mixed ferro-ferrimagnets composed of Prussian blue analogs. Phys. Rev. B 1997, 56, 11642-11652. [CrossRef]

54. Ohkoshi, S.; Abe, Y.; Fujishima, A.; Hashimoto, K. Design and Preparation of a Novel Magnet Exhibiting Two Compensation Temperatures Based on Molecular Field Theory. Phys. Rev. Lett. 1999, 82, 1285-1288. [CrossRef] 
55. Shannon, R.D. Revised Effective Ionic Radii and Systematic Studies of Interatomic Distances in Halides and Chalcogenides. Acta Cryst. 1976, A32, 751-767. [CrossRef]

56. Herrera, J.M.; Franz, P.; Podgajny, R.; Pilkington, M.; Biner, M.; Decurtins, S.; Stoeckli-Evans, H.; Neels, A.; Garde, R.; Dromzée, Y.; et al. Three-dimensional bimetallic octacyanidometalates $\left[\mathrm{M}^{\mathrm{IV}}\left\{(\mu-\mathrm{CN})_{4} \mathrm{Mn}^{\mathrm{II}}\left(\mathrm{H}_{2} \mathrm{O}\right)_{2}\right\}_{2} \cdot 4 \mathrm{H}_{2} \mathrm{O}\right]_{n}(\mathrm{M}=\mathrm{Nb}, \mathrm{Mo}, \mathrm{W})$ : Synthesis, single-crystal X-ray diffraction and magnetism. Comptes Rendus Chim. 2008, 47, 6885-6887. [CrossRef] 